\title{
The Analysis of The Work Environmental and Organizational Cultural Impact on The Performance and Implication of The Work Satisfaction
}

\author{
Denok Sunarsi \\ Pamulang University \\ Email: denoksunarsi@unpam.ac.id
}

(Received: Juny 20-2019; revised: December 22-2019; published: December 31-2019)

\begin{abstract}
This study aimed at analyzing the impact of the work environment and organizational culture on its performance and implications for the satisfaction of elementary school teachers in the region of Bogor West Java. The method of data analysis uses quantitative decryptive analysis techniques in which its population is an entire elementary school teacher in the region of Bogor - West Java which the total are 18,653 . While on collecting sample, the writer used the slovin formula with a $10 \%$ error rate in which a 99.47 collected amount of samples would be 100 responders. Research results confirm that (1). The work environment has a partial positive and significant effect on the performance; (2). Organizational culture has a partial positive and significant effect on performance; (3). The work environment and organizational culture simultaneously have a positive and significant impact on the performance; (4). The work environment has a partial positive and significant impact on work satisfaction; (5). Organizational culture has a partial positive and significant impact on work satisfaction; (6). Partial performance has a positive and significant impact on work satisfaction. (7). Work environment, an organizational culture and performance simultaneously have a positive and significant impact on performance.
\end{abstract}

Key Words: Work Environment, Organizational Culture, Performance, Satisfaction

\section{INTRODUCTION}

The Good and qualified education is not apart from the role of a teacher, according to the government regulation of the Indonesian republic of 19, 2017, for a change in government regulation number 74 in 2008 "teacher is the professional workforce who having a strategic role to realize the vision of an arrangement of learning in accordance with professional principles", Working environment or well-financed infrastructure and a well-aimed organization's culture will be able to improve the teacher's performance in carrying out the teaching activity, when all these components are realized the teacher's satisfaction in teaching will be able to create the qualified learners (Sunarsi \& Kusjono, 2019).

Because of the importance of the teacher's performance factor in his role to improve education's success, so keeping and seeking to make the teacher has a high performanceis is absolutely necessary. The factors affect a teacher's performance improvement need to be sought for answers quickly in order to have a problem with improving education soon.

One way to improve the performance of a teacher's work is giving him some motivations such as by having recreation or family gathering while the students complete the national exam, assigning awards to the excelling teachers and so on. The teachers are the key to improving the 
238| Jurnal Ilmiah Ilmu Administrasi Publik: Jurnal Pemikiran dan Penelitian Administrasi Publik

Volume 9 Number 2,July - December 2019. Page 237-246

quality of education, because the essential requirement for a good education is when its implementation is done by educators were completely professional.

In that implementation requires a change of attitude and actions from the entire school component, both the principal, the teachers and the administration staff, including parents and the public's view, understanding and helping as also a monitor through monitoring and evaluation in school performance. The change in attitude and that actions will be able to happen when the school's resources are being exploited and managed optimally and effectively by the headmaster as a person in charge of administrating the school's education.

Wakhid (2014) said the conducive work environment provides a sense of security and enables employees to work optimal. Work environment can affect employees' emotional state. If an employee likes the work environment in which he works, so the employee will feel comfortable with his job, doing his activities so his work time can be used effectively. The productivity will increase and automatically the work performance of employees also increases. The work environment includes a work relationship between feudatory and superior and the physical environment in which the employees work. Work environment factors are mutually beneficial for individuals in accomplishing work performance. Among the work environment factors are: (1) health, (2) security, (3) service, (4) pattern of communication, and (5) work facilities.

From the preliminary observation, the author found many problems related to primary school teachers' work environment in the bogor county area, among them are dusty and dirty conditions of the environment, and hot air circulation. One of the causes of it is that most of the bogor district is exploitation of sand and rock area so that the teacher's work environment both in the office and the classroom feels inadequate. The uncomfortable classroom, the noise sound because the location on the side of the road, and inadequate infrastructure, causing some teachers lose their spirit to teach then the students are not able to get a good quality of learning (Farida, 2017).

(Sedarmayanti (2001) the work environment is the total tool and material that are encountered, the surroundings where a person works, his or her work methods, and work arrangements both as individuals and as groups. According to (Nitisemito (2010) the work environment is everything around the worker and can affect him in performing the borne tasks. Such as hygiene, music and so on.

The work environment can create a binding working relationship between the people within the community. Therefore, a working environment should be good and conducive to work because a good working environment will make the employee comfortable and has spirit to do each of his or her duties (Chandrasekar, 2011). According to Schultz \& Schultz (2015) the environment or working conditions are all physical working aspects, occupational psychology and work regulations that can affect the job satisfaction and productivity of work. In the context of working environments, Sunusi (2016) stated that the work environment can create a binding work relationship between those within the community. Therefore, the work environment should be good and conducive because a good working environment will make the employees feel comfortable and have spirit to do each of their duties. From those standpoint, so it can be concluded that the work environment is everything around the employee and can influence him in performing his assigned duties.

Equal to the work environment, the organizational culture is also important for teachers to create a conducive and focused work environment, the organizational culture can be defined in 
various ways, the organizational's cultural definition often presented by experts. According to (Stephen \& Judge, 2002) stated, "the organizational culture is a set of values, principles, traditions, and the ways of working that are followed by members of the organization and influence how they act". Bright \& Cooper (1993) stated that the organizational culture is a pattern of belief and values that is understood, imbued, and practiced by the organization so that the pattern provides its own meaning and becomes the fundamental rule of behavior in the organization, while Schein (2010) assumed that the organizational culture is a fundamental assumption found, Created and developed by a particular group in order for the organization to learn to solve or to handle the problems resulting from well-handled extrernal and internal adaptation, thus it is needed to teach the new members the proper way to understand, think, and feel on these problems.

Thus, it can be concluded that the organizational culture is a pattern of belief and values which all its members contribute in the work as a proper way to understand, think, and feel about related problems, so there will be a value or rule in the organization. With a good working environment and a dedicated organizational culture, so it will increase the teacher's performance to achieve the designated target, which is to create the qualified students and to achieve a full national education goal (Saggaf, Akib, Salam, Baharuddin, \& Kasmita, 2018; Saggaf, Nasriyah, Salam, \& Wirawan, 2018).

According to Richard (2010) the word 'kinerja' is a translation of the performance that means work accomplishment, work implementation, work achievement or work appearance. The success of an organization is so closely related to the quality of performance of its members, so it is required to always develop and improve the performance of its members. The performance is the result that can be demonstrated or the appearance of the employee. Thus, an employee's performance can be measured by the results of work, assignments, or activities within a period of time (Notoatmodjo, 2009). According to Dall'Ora, Ball, Recio-Saucedo, \& Griffiths (2016) stated "employee's performance is a comparison of the results which is achieved by the participation of the employee per unit of time". According to Bouckenooghe, Zafar, \& Raja (2015) was " A work performance or the work result (output) of both the quality and quantity which is attained by human resources per unit of time periods in performing his work according to the responsibilities given to him."

Based on some opinions it can be concluded that performance is the results of the activities were done by employees after being limited by the time and purpose. That work have to be restricted so it can be completed according to the designated target, and not deviate from the company's goals. Furthermore, in order to the work activities can be done according to the standards and procedures, so it can run effectively and efficiently. With the good performance, the process of learning and teaching activity produces qualified students, so it will give the sense of satisfaction to the teachers for what they have done over a period of time.

According to Hayes, Douglas, \& Bonner (2015) "work satisfaction is connected with one's feelings or attitudes about the job itself, salary, promotion opportunities or education, control, workmates, workload, and so on. He continued his statements that the work satisfaction relates to one's attitude about work, and there are some practical reasons that make job satisfaction is an important concept for a leader. The studies demonstrate that the satisfied workers are more likely to endure with their the job for the organization. The satisfied workers 
240 Jurnal Ilmiah Ilmu Administrasi Publik: Jurnal Pemikiran dan Penelitian Administrasi Publik Volume 9 Number 2,July - December 2019. Page 237-246

also tend to engage in organizational behaviors that transcend their job description and role, and help to reduce the workload and stress levels of members in the organization. The disgruntled (Saggaf, Akib, et al., 2018; Saggaf, Nasriyah, et al., 2018)counterproductive behaviors (Sunarsi \& Yuliani, 2019)(Niswaty, Juniati, Darwis, Salam, \& Arhas, 2019). "The importance in managers on work satisfaction tends to focus on the performance effect of employees. The researchers recognize these importances, because many studies are designed that the effects of work satisfaction on productivity, absence, and employee resignation"(Motlou, Singh, \& Karodia, 2016).

Whereas, according to (Pundt, Wöhrmann, Deller, \& Shultz, 2015), work satisfaction is influenced by many factors, among them are: (a). Fair and deserving retribution; (b). Proper placement and craftsmanship; (c). Workload; (d). Work environment; (e). Supporting tools; (f). Leadership. According to (Sutrisno, 2019) work satisfaction is influenced by several factors, such as: (a). Salary; (b). Security; (c). Opportunities to advance; (d), management and business; (e). Supervision and superior. A bad visionary causes the absentees and turnovers; (f) Intrinsic factor of work. The difficulty levels of work and the pride on duty can increase or decrease the work; (g) Working conditions include cafeteria, ventilation, parking and distribution; Social aspects in the work; (h). Communication; and (j). corporate facilities. From some standpoints of work satisfication referred to by experts, so the writer concluded that work satisfication is either a circumstance and a condition where the employees are satisfied or not in performing their job.

The results of this study are expected to provide information that is beneficial for various parties, could provide information and input to the goverment of west java district of bogor to take policies in an effort to improve quality of education,especially at the elementary educayional level in an effoert to achieve national objective, then as a reference material to increas knowledge and to present information about work environment organizational satisfication,broading the insight and expanding the knowledge of researchers in reserch factor such as barriers to national educational objectives and this result is expected to be a source of information for us as a reference and fondation in further reserch.

\section{METHOD}

Data analysis method which used in this research is quantitative descriptive analysis technique in which its population is all elementary school teachers in Bogor Regency, West Java Province, Indonesia in 2018-2019, which amount to 18.653. Meanwhile, in sampling, the author used Slovin formula with $10 \%$ error level where after calculated, there are 99,47 sample which was fulfilled to 100 resondents.

Activities in analyzing data are group data by variables, tabulate data, present data from each variable studied, perform calculations in order to answer formulation of the problem and in order to test the hypotesis that has been proposed. As for testing this instrument there are 2 (two) tests used, that are 1) Validity Test and 2) Reliability Test.

Data eligibility or clasical assumption used to know the accuracy of a data. According to Ghinea et al., (2016) a regression model that will be used to forecast a good model is a model with the error of forecasting as small as posible. Therefore, a model, before it was used, necesarily to fulfill some assumptions that commonly called 'classical assumption'. In this research, the classical assumption test that used are: Normality Test, Multicollinearity Test, and Heteroscedasticity. 
In this research, data that used is Descriptive and Verificative Analysis, therefore, this research demanded researcher to do analysis and studied systematically, deeply, and meaningful, this descriptive analysis will giving an illustration about a data that will be researched that can helped in order to know the characteristic of sample data, analysis was done by looking at the frequency from the option by respondent that was provided in each questionnare that given. Meanwhile, verificative analysis, usually also called as quantitative, that is the research to appraise the condition of infulence value, and the significance of that infulence. The analysis stages that carried out are 1) Correlation coefficient analysis, 2) Analysis of the coefficient of determitation 3) Path Analysis and 4) Hypotesis testing. This research was finished with drawing conclusion, in this research, drawing conclusion answers what has been formulated base on the results of research that has been done processing and analyzing data with the help of the SPSS program for Windows 24.

\section{RESULT AND DISCUSSION}

\section{Result}

The result of data processing can be obtained information base on the result of calculations with the path analysis model as follows.

\section{Model-1}

1. The contribution of the work environment to performance is $0.3522=0.124(12.4 \%)$.

2. The contribution of organizational culture to performance is $0.3912=0.153(15.3 \%)$.

3. The contribution of work environment and organizational culture simultaneously to the performance was $\mathrm{R}_{\text {square }}^{2}=0.316$ or $31.6 \%$ and the remaining $68.4 \%$ were not identified in this study.

\section{Model-2}

Direct and indirect effects (through $\mathrm{Y}$ ) and the total effect of the work environment $\left(\mathrm{X}_{1}\right)$, organizational culture $\left(\mathrm{X}_{2}\right)$, and performance $(\mathrm{Y})$ on $\mathrm{Z}$ can be described as follows.

\section{a. Effects of $X_{1}$ to $Z$ and $X_{1}$ to $Z$ Through $Y$}

The direct effect of the work environment coefficient on job satisfaction is 0.198 , while the indirect effect of the work environment $\left(X_{1}\right)$ on job satisfaction through performance is:

$=0.198+(0.352 \times 0.389)$

$=0.198+0.137$

$=0.335$

It means that it can be concluded that the total effect of the work environment on job satisfaction is 0.335 .

b. Effects of $X_{2}$ to $Z$ and $X_{2}$ to $Z$ Through $Y$ 
242 Jurnal Ilmiah Ilmu Administrasi Publik: Jurnal Pemikiran dan Penelitian Administrasi Publik Volume 9 Number 2,July - December 2019. Page 237-246

The direct effect of organizational culture coefficient on job satisfaction is 0.217 , while the indirect effect of organizational culture $\left(\mathrm{X}_{2}\right)$ on job satisfaction through performance is:

$=0.217+(0.391 \times 0.389)$

$=0.217+0.152$

$=0.369$

It means that it can be concluded that the total influence of organizational culture on job satisfaction is 0.369

c. The value of the contribution of the work environment $\left(\mathrm{X}_{1}\right)$ directly to job satisfaction $(\mathrm{Z})$ is $0.1982=3.9 \%$

d. The value of the contribution of organizational culture $\left(\mathrm{X}_{2}\right)$ directly to job satisfaction $(\mathrm{Z})$ is $0.2172=4.7 \%$

e. The value of the contribution of performance $(\mathrm{Y})$ directly to job satisfaction $(\mathrm{Z})$ is $0.3892=$ $15.13 \%$

f. While the contribution of the work environment, organizational culture, and employe performance simultaneously to customer satisfaction is 0.387 or $38.7 \%$ and the rest $61.3 \%$ are other factors not identified in this study.

The following is a summary of path coefficients both direct and indirect effects of the work environment $\left(\mathrm{X}_{1}\right)$, organizational culture $\left(\mathrm{X}_{2}\right)$ and performance $(\mathrm{Y})$ on job satisfaction $(\mathrm{Z})$.

Table 1

Summary of Direct and Indirect Model Path Coefficients

\begin{tabular}{|c|c|c|c|c|}
\hline \multirow{2}{*}{$\begin{array}{c}\text { Influence Of } \\
\text { Variables }\end{array}$} & \multicolumn{2}{|c|}{ Causal Influence } & \multirow{2}{*}{$\begin{array}{l}\text { Residue } \\
\varepsilon_{1} \text { And } \varepsilon_{2}\end{array}$} & \multirow{2}{*}{ Total } \\
\hline & Directly & Indirectly Through Y & & \\
\hline \multirow{2}{*}{$\mathrm{X}_{1}$ Through Z } & 0.198 & - & - & 0.198 \\
\hline & - & $0.198+(0.352 \times 0.389)$ & - & 0.335 \\
\hline \multirow{2}{*}{$\mathrm{X}_{2}$ Through Z } & 0.217 & - & - & 0.217 \\
\hline & - & $0.217+(0.391 \times 0.389)$ & - & 0.369 \\
\hline $\begin{array}{c}\mathrm{X}_{1} \mathrm{X}_{2} \mathrm{Y} \text { Through } \\
\mathrm{Z}\end{array}$ & 0.387 & - & 0.613 & 1 \\
\hline $\mathrm{X}_{1}$ Through Y & 0.352 & - & - & 0.352 \\
\hline $\mathrm{X}_{2}$ Through Y & 0.391 & - & - & 0.391 \\
\hline $\mathrm{X}_{1} \mathrm{X}_{2}$ Through $\mathrm{Y}$ & 0.316 & - & 0.684 & 1 \\
\hline
\end{tabular}

Based on statistical tests that have been carried out to answer the formulation of the proposed problem, as well as proof of the hypothesis or provisional answers based on theory. Then the authors can describe the results of research based on statistical tests as follows.

\section{Structure Model 1}

a. Effect of work environment on performance 
Based on the results of statistical tests on the structure model-1 for the first hypothesis is proven $\mathrm{Ha}$ is accepted and Ho is rejected, where the value of $\mathrm{t}$ count $>\mathrm{t}$ table $(4.149>1.98)$ and $\mathrm{Sig}<0.05(0.000<0.05)$. This means that the work environment variables partially have a positive and significant effect on performance.

b. The influence of organizational culture $\left(\mathrm{X}_{2}\right)$ on performance $(\mathrm{Y})$

Based on the results of statistical tests partially on the structure model-1 for proof of the second hypothesis is proven $\mathrm{Ha}$ is accepted and Ho is rejected, where the value of $\mathrm{t}$ count $>\mathrm{t}$ table $(4.609>1.98)$ and $\mathrm{Sig}<0.05(0.000<0.05)$. This means that organizational culture variables partially have a positive and significant effect on performance.

c. Effect of work environment and organizational culture on performance

Based on the results of simultaneous statistical tests on the structure-1 model to prove the third hypothesis is proven $\mathrm{Ha}$ is accepted and Ho is rejected, where the calculated F value $>$ F table $(22.434>3.09)$ and Sig $<0.05(0.000<0.05)$. This means that the work environment and organizational culture simultaneously have a positive and significant effect on performance.

\section{Structure Model 2}

a. Effect of work environment $\left(\mathrm{X}_{1}\right)$ on job satisfaction $(\mathrm{Z})$

Based on statistical test results on the 2-structure model to prove the fourth hypothesis is proven $\mathrm{Ha}$ is accepted and Ho is rejected, where the value of $\mathrm{t}$ count $>\mathrm{t}$ table $(2.255>1.98)$ and Sig <0.05 $(0.026<0.05)$. This means that the work environment variables partially have a positive and significant effect on job satisfaction.

b. The influence of organizational culture $\left(\mathrm{X}_{2}\right)$ on job satisfaction $(\mathrm{Z})$

Based on statistical test results on the 2-structure model to prove the fifth hypothesis is proven $\mathrm{Ha}$ is accepted and Ho is rejected, where the value of $\mathrm{t}$ count $>\mathrm{t}$ table (2.433> 1.98) and Sig <0.05 $(0.017<0.05)$. This means that organizational culture variables partially have a positive and significant effect on job satisfaction.

c. Effect of performance (Y) on job satisfaction (Z)

Based on statistical test results on the 2-structure model to prove the sixth hypothesis is proven $\mathrm{Ha}$ is accepted and Ho is rejected, where the value of $\mathrm{t}$ count $>\mathrm{t}$ table (4.026> 1.98) and Sig <0.05 $(0.000<0.05)$. This means that the performance variable partially has a positive and significant effect on job satisfaction. 
244 Jurnal Ilmiah Ilmu Administrasi Publik: Jurnal Pemikiran dan Penelitian Administrasi Publik Volume 9 Number 2,July - December 2019. Page 237-246

d. Effect of work environment $\left(\mathrm{X}_{1}\right)$, organizational culture $\left(\mathrm{X}_{2}\right)$ and performance $(\mathrm{Y})$ on job satisfaction (Z) simultaneously

Based on the results of simultaneous statistical tests on the 2-structure model for the seventh hypothesis is proven $\mathrm{Ha}$ is accepted and Ho is rejected, where the calculated $F$ value $>$ F table $(20,206>2.69)$ and Sig <0.05 $(0.000<0.05)$. This means that the work environment, organizational culture and performance simultaneously have a positive and significant effect on performance.

\section{Discussion}

Descriptive discussion, intended for exploration and clarification of social phenomena or reality, by describing a number of variables relating to the problem under study.

\section{The Situation Or Criteria Of The Object Under Study Based On Work Environment Variables $\left(\mathbf{X}_{1}\right)$.}

Work environment is the overall work infrastructure that exists around employees who are carrying out work that can affect the work itself, the work environment is designed in such a way as to create a work relationship that binds workers with the environment. Overall condition or criteria for the work environment variable questionnaire $\left(\mathrm{X}_{1}\right)$ obtained an average score of 3.97 where the value is in the scale range of $3.40-4.19$ with good criteria.

\section{The Situation or Criteria of The Object Under Study Based On Organizational Culture Variables $\left(\mathbf{X}_{2}\right)$.}

Organizational culture is the basic assumptions that are found, created and developed by a particular group with the intention that the organization learns to overcome or deal with problems arising from external and internal adaptations that have been going well enough, so it needs to be taught to new members as a correct way to understand, think about, and feel about these problems. The overall condition or criteria for the organizational culture variable $\left(\mathrm{X}_{2}\right)$ questionnaire obtained an average score of 4.03 where the value is in the scale range of $3.40-4.19$ with good criteria.

\section{The State or Criteria Of The Object Under Study Are Based On The Performance Variable (Y).}

Performance means the work that can be displayed or the work performance of an employee. Thus, an employee's performance can be measured from the results of work, task results, or the results of activities within a certain period of time. Overall condition or criteria for the Performance variable questionnaire (Y) obtained an average score of 4.08 where the value is in the scale range of $3.40-4.19$ with good criteria.

\section{The State or Criteria Of The Object Under Study Are Based On The Variable Job Satisfaction (Z).}


Job satisfaction as a combination of psychological, physiological and environmental causes an individual likes his work. A person with a high level of job satisfaction has a positive attitude towards his work, someone who is dissatisfied with his job has a negative attitude towards the job. The overall condition or criteria of respondents' answers to the job satisfaction variable questionnaire $(\mathrm{Z})$ obtained an average score of 4.29 where the value is in the scale range of $4.19-5.00$ with very good criteria.

\section{CONCLUSION}

According to the results of the study it can be concluded: 1) Effect Of Work Environment $\left(\mathrm{X}_{1}\right)$ On Performance $(\mathrm{Y}), 2$ ) Effect of Organizational Culture $\left(\mathrm{X}_{2}\right)$ On Performance (Y), 3) Effect Of Work Environment $\left(\mathrm{X}_{1}\right)$ and Organizational Culture $\left(\mathrm{X}_{2}\right)$ On Performance $\left.(\mathrm{Y}), 4\right)$ Effect Of Work Environment ( $\left.X_{1}\right)$ On Job Satisfaction $\left.(Z), 5\right)$ The influence of organizational culture $\left(\mathrm{X}_{2}\right)$ on job satisfaction $\left.(\mathrm{Z}), 6\right)$ Effect of performance $(\mathrm{Y})$ on job satisfaction $\left.(\mathrm{Z}), 7\right)$ Effect of work environment $\left(\mathrm{X}_{1}\right)$, organizational culture $\left(\mathrm{X}_{2}\right)$ and performance $(\mathrm{Y})$ on job satisfaction $(\mathrm{Z})$ simultaneously.

\section{REFERENCES}

Bouckenooghe, D., Zafar, A., \& Raja, U. (2015). How ethical leadership shapes employees' job performance: The mediating roles of goal congruence and psychological capital. Journal of Business Ethics, 129(2), 251-264.

Bright, K., \& Cooper, C. L. (1993). Organizational culture and the management of quality: towards a new framework. Journal of Managerial Psychology, 8(6), 21-27.

Chandrasekar, K. (2011). Workplace environment and its impact on organisational performance in public sector organisations. International journal of enterprise computing and business systems, 1(1), 1-19.

Dall'Ora, C., Ball, J., Recio-Saucedo, A., \& Griffiths, P. (2016). Characteristics of shift work and their impact on employee performance and wellbeing: A literature review. International journal of nursing studies, 57, 12-27.

Farida, U. (2017). Analysis of Empowerment Program that was Implemented in Mamuju Regency East Sulawesi Indonesia. 149(Icest), 19-21.

Ghinea, C., Drăgoi, E. N., Comăniţă, E.-D., Gavrilescu, M., Câmpean, T., Curteanu, S., \& Gavrilescu, M. (2016). Forecasting municipal solid waste generation using prognostic tools and regression analysis. Journal of environmental management, 182, 80-93.

Hayes, B., Douglas, C., \& Bonner, A. (2015). Work environment, job satisfaction, stress and burnout among haemodialysis nurses. Journal of nursing management, 23(5), 588-598.

Motlou, R. G., Singh, S., \& Karodia, A. M. (2016). An evaluation of the impact of job satisfaction on employee retention at Lonmin Rowland Shaft North West province. Kuwait Chapter of Arabian Journal of Business and Management Review, 33(3421), 1-35.

Niswaty, R., Juniati, F., Darwis, M., Salam, R., \& Arhas, S. H. (2019). The Effectiveness of 
246 Jurnal Ilmiah Ilmu Administrasi Publik: Jurnal Pemikiran dan Penelitian Administrasi Publik Volume 9 Number 2,July - December 2019. Page 237-246

Leadership Functions Implementation in The Makassar Departement of Manpower. JPBM (Jurnal Pendidikan Bisnis dan Manajemen), 5(1), 1-10.

Nitisemito, A. S. (2010). Manajemen Personalia Sumber Daya Manusia. Gholia.

Notoatmodjo, S. (2009). Pengembangan Manajemen Sumber Daya Manusia. Penerbit Rineka Cipta, Jakarta.

Pundt, L. M., Wöhrmann, A. M., Deller, J., \& Shultz, K. S. (2015). Differential predictors of post-retirement life and work satisfaction. Journal of Managerial Psychology, 30(2), 216231.

Richard, L. (2010). Era Baru Manajemen. Edward Tanujaya, Edisi, 9.

Saggaf, M. S., Akib, H., Salam, R., Baharuddin, A., \& Kasmita, M. (2018). The Quality Analysis Of Academic Services.

Saggaf, M. S., Nasriyah, N., Salam, R., \& Wirawan, H. (2018). The Influence of Teacher's Pedagogic Competence on Learning Motivation of Student of Office Administration Expertise Package.

Schein, E. H. (2010). Organizational culture and leadership (Vol. 2). John Wiley \& Sons.

Schultz, D., \& Schultz, S. E. (2015). Psychology and Work Today: Pearson New International Edition CourseSmart eTextbook. Routledge.

Sedarmayanti. (2001). Sumber daya manusia dan produktivitas kerja. Bandung: CV. Mandar Maju.

Stephen, R., \& Judge, T. A. (2002). Prinsip-prinsip perilaku organisasi. Terjemahana Helida, Dewi Sartika, Erlangga Jakarta.

Sunarsi, D., \& Kusjono, G. (2019). Pengaruh Lingkungan Kerja Non Fisik, Konflik dan Turn Over Intention terhadap Produktivitas Kerja Karyawan pada CV. Usaha Mandiri Jakarta Selatan. Jurnal Ekonomi Efektif, 1(3).

Sunarsi, D., \& Yuliani, I. (2019). Pengaruh Gaya Kepemimpinan dan Budaya Organisasi terhadap Kinerja Karyawan pada Bank BTN Kantor Cabang Tangerang. JURNAL SeMaRaK, 2(1).

Sunusi, S. (2016). Determinan Implementasi Kebijakan Pengembangan Sumber Daya Aparatur Pemerintah Daerah Kabupaten Sidenreng Rappang. Jurnal Ilmiah Ilmu Administrasi Publik, 6(1), 61-68.

Sutrisno. (2019). Budaya organisasi. Prenada Media.

Wakhid, G. A. (2014). Pengaruh Lingkungan Kerja dan Motivasi Kerja terhadap Kinerja Pegawai pada Sekretariat Daerah Kabupaten Kota Baru. Jurnal Kindai, 10(1), 65-77. 